\title{
Sovereign debt restructuring in the EU: lessons from the recent crisis
}

\author{
Alexander, Kern
}

DOI: https://doi.org/10.4337/9780857936639.00019

Posted at the Zurich Open Repository and Archive, University of Zurich ZORA URL: https://doi.org/10.5167/uzh-55141

Book Section

Originally published at:

Alexander, Kern (2011). Sovereign debt restructuring in the EU: lessons from the recent crisis. In: Sethe, Rolf; et al. Kommunikation: Festschrift für Rolf H. Weber zum 60. Geburtstag. Bern: Stämpfli, 803-820. DOI: https://doi.org/10.4337/9780857936639.00019 


\title{
Sovereign Debt Restructuring in the EU: Lessons from the Recent Crisis
}

\author{
KERN ALEXANDER *
}

\section{Contents}

I. Introduction..................................................................... 803

II. The Greek Crisis and the Sovereign Debt Problem ........................ 805

1. The Greek Crisis................................................................. 805

2. The Mexican 'Tesobono' Crisis ......................................... 806

3. European Monetary Fund ................................................ 808

III. European Financial Stability Facility (EFSF) ............................. 809

IV. Reforming Sovereign Debt Restructuring in the EU ................... 812

1. A Decentralized EU Institutional Approach.......................... 813

a) Collective Action Clauses (CACs) ............................... 813

b) Implementation ....................................................... 815

2. EU Financial Stability Fund ......................................... 817

3. EU Stability Mechanism.................................................... 818

V. Conclusion ...................................................................... 819

\section{Introduction}

The global financial crisis has led to a severe recession in Europe culminating in sovereign debt problems for many eurozone governments. Greece was particularly hard hit because of fiscal mismanagement and unsustainably high levels of public debt, resulting in an extraordinary and unprecedented bailout by eurozone governments and the International Monetary Fund (IMF), with the creation of the European Financial Stabilization Mechanism ${ }^{1}$ and the European Financial Stability Facility (EFSF). The EU sovereign debt crisis of 2010-2011 demonstrates the inadequate macroeconomic crisis management

\footnotetext{
I would like to thank KARIN LOREZ, URS HOFER and MELANIE WYSS for their research assistance. In a previous commissioned report, entitled 'Market Impact of an Orderly Sovereign Debt Restructuring' (Sept. 2010), the author proposed the mandatory use of collective action clauses (CACs) for EU sovereign bond contracts and a permanent sovereign liquidity mechanism. The CAC proposal was later adopted by the European Council in December 2010.

1 To pay for the Greek bailout, the EU created the EFSM in 2008 to lend up to 60 billion euros to EU member states experiencing financial difficulties arising mainly from international trade finance. The EU used the fund along with additional IMF financial support to help pay the 110 billion euro bailout for Greece in May 2010. The EFSM will not be addressed further in this chapter.
} 
framework in the EU and the need to establish a more orderly sovereign debt restructuring process.

Europe has not had a legal or formal institutional framework to resolve a sovereign debt default or restructuring. Indeed, the Greek crisis and the growing sovereign debt problems of other EU states raise important questions about whether EU policymakers should establish a formalized institutional process across the EU to promote a more orderly sovereign debt restructurings. The chapter analyses a number of corollary questions about how such a process could work without undermining market discipline, and what powers, if any, should be allocated to EU institutions to oversee sovereign debt restructurings and whether this complies with the EU treaties. It further examines what set of principles should guide policymakers in devising such an institutional framework and whether this could help indebted countries avoid a damaging loss of investor confidence and destabilizing market volatility.

The themes addressed in this chapter relate to some of the important issues examined by Professor ROLF H. WEBER in his distinguished academic career in the areas of economic governance, financial regulation and financial law reform. Professor Weber's analytical framework for analysing the institutional structure of financial regulation and the development of financial law has inspired scholars from across disciplines, but especially academic lawyers, in designing intellectual frameworks to analyse the role of law and regulation in creating institutions of effective economic governance.

This chapter was inspired by Professor Weber's work in the field of European financial law and regulation. The chapter examines what type of orderly sovereign debt restructuring arrangements should be established in the EU and how it can address the type of liquidity and solvency problems which Member States have been experiencing in the recent sovereign debt and financial crisis. In evaluating the first question, the chapter reviews the proposal for a European Monetary Fund (EMF) and the operational structure of the EFSF. These approaches intend to remove the risk of disorderly default, which is the main risk that countries in a fiscal crisis pose to financial stability in the euro-area. The establishment of the EFSF has brought some stability to European financial markets and has resulted in lower spreads on the sovereign debt of Greece, Ireland and other vulnerable euro-area states, but spreads remain high for these countries, which reflects inadequate market confidence in their fiscal sustainability and a concern that the EFSF is only a short-term measure designed to restore investor confidence in eurozone sovereign debt.

The chapter argues that the EU should adopt a decentralized sovereign debt default and restructuring process that emphasizes the use of collective action clauses (CACs) to facilitate negotiations and restructuring creditor claims when a sovereign is experiencing financial difficulties. EU legislation should harmonize the principles and guidelines that govern the operation of CACs, but parties should be permitted some freedom to decide certain CAC 
repayment terms and some of the parameters of the restructuring process. Also, EU institutions should create an EU sovereign debt agency that would oversee the application of EU principles and guidelines for Member State sovereign debt negotiations and contract formation and would provide market data on sovereign debt markets to market participants and sovereigns. The EU sovereign debt agency could also administer a European Financial Stability Fund that would be created to provide liquidity to states experiencing financial distress if the state in question fulfils the requisite conditions for obtaining support. The Fund would be financed by a small transaction tax on all sovereign bond trading and derivative instruments.

\section{The Greek Crisis and the Sovereign Debt Problem}

\section{The Greek Crisis}

The problems arising from the Greek sovereign debt crisis raise important issues regarding how the EU and the eurozone institutions should assist Member States which are experiencing liquidity and/or solvency problems. The EU Stability and Growth Pact (SGP) presently requires Member States not to run annual budget deficits in excess of $3 \%$ of gross domestic product (GDP) and not to have national debt in excess of $60 \%$ of GDP. The Pact's effectiveness has been undermined because of the failure of the EU Council to enforce its rules consistently across states and the inflexible application of its deficit and debt rules regardless of a state's position in the economic cycle. Indeed, the Pact's inflexible rules can be characterized as having resulted in neither growth nor stability.

The EU lacks a fiscal policy dimension to assist states experiencing financial difficulties in crisis situations. Article 125 of the Treaty on the Functioning of the European Union (TFEU) prohibits EU institutions from bailing out EU states experiencing fiscal problems. ${ }^{2}$ Article 122 TFEU, however, provides the legal basis for EU institutional and Member State support, as it calls for political and financial solidarity with Member States that are in severe difficulties. Paragraph 2 of Article 122 authorizes the Council to grant financial assistance from the Union to a Member State if the state in question is in, or seriously threatened with, severe difficulties caused by natural disasters or 'exceptional occurrences beyond its control'. Although a state facing serious budgetary constraints and financing problems would certainly not qualify for the natural disaster exception, it might qualify under the language of 'exceptional occurrences beyond its control' on the grounds that a self-inflicted budgetary limitation in combination with a global financial crisis that caused

Article 125 (1) TFEU excludes the allocation of liability to the Union and the Member States for the commitments of another Member State. 
a substantial reduction in the country's GDP is an exceptional occurrence beyond its control.

Based on the Treaty provisions, the EU could adopt institutional reforms that provide state guarantees to Member States experiencing serious financial difficulties the causes of which are partly beyond their control. The mismanagement of the Greek economy, exacerbated by the collapse of world trade and hence the collapse of shipping revenues, led to cumulative severe pressures on the bond sales necessary to fund the Greek government deficit. Since Greek government bonds are denominated in euros, investors faced no currency risk. However, they did face increasing fears of default. The reaction in European capitals was to initiate a protracted, indecisive debate on raising the funds for a Greek 'bailout'. As vague pronouncements were piled on indecision, the fear of default increased, so that when the EUR 120 billion bailout was at last agreed, it proved inadequate as a defence against the rising tide of default pessimism. The Greek crisis, along with the recent sovereign debt difficulties of a number of EU states, has defined the shape of necessary institutional and market reforms to be considered in this chapter.

\section{The Mexican 'Tesobono' Crisis}

The confused handling of the Greek crisis stands in stark contrast to the rapid and effective measures taken by the United States Government in the Mexican debt crisis of December 1994, which was very similar in important respects to the Greek crisis. The Mexican government had borrowed billions of dollars of short-term US dollar denominated debt when the economy was growing. When Mexico fell into a severe recession in 1994, it was forced to devalue the peso. This drove up the value of its sovereign bonds or 'tesobonos', as they were known. Investors in Mexican government tesobonos faced a complex mixture of currency risk and default risk.

By late 1994, Mexican government finances were collapsing with USD 25 billion coming due in a few months while central bank reserves had fallen to less than USD 6 billion. In devising a rescue plan, US policymakers and the IMF had not forgotten the Latin American debt crisis of 1982 in which the Mexican government had defaulted on USD 80 billion in loans from large mainly US - banks, creating a contagion that spread rapidly across Latin American countries, causing them to seek emergency refinancing of their US dollar denominated loans from foreign banks. The US government intervened with guarantees for the loans only after defaults led to the near failure of several large US banks: the US's slow response in providing emergency liquidity support in the form of loan guarantees worsened the crisis and plunged Latin America into a severe recession that stunted its economic development for nearly a decade. 
In contrast, during the 1994 Mexican crisis, the Clinton administration, acting with support from the IMF, assembled a USD 50 billion emergency package in a few days, predominantly in the form of guarantees, which stemmed the investor run and rapidly restored confidence. ${ }^{3}$ Although the 1994 crisis was smaller than the Latin American crisis of the early 1980s, it could have threatened financial stability throughout Latin America and in other developing countries. ${ }^{4}$ Moreover, the growing integration of international trade and financial markets suggests that the negative externalities of financial risk-taking can spread more quickly across borders and threaten global financial stability.

In contrast, if a credible eurozone institution had guaranteed Greek bonds at the outset and had imposed adequate fiscal adjustments and facilitated restructuring of bondholder claims, the immediate crisis would probably have been over sooner, at much lower costs. Instead, the eurozone's leading states, Germany and France - dithered and allowed the Greek crisis to worsen considerably. It was not until an emergency meeting of EU finance ministers held on 9 May 2010 where they agreed to adopt an extraordinary rescue package guaranteeing all of Greece's sovereign bonds and the bonds of other eurozone members by establishing an off-balance sheet entity which would issue bonds worth up to EUR 660 billion (including an IMF USD 250 billion facility) to banks and other investors which would be fully guaranteed by eurozone states. The emergency rescue package essentially bailed out the banks and other creditors who had purchased Greek sovereign debt and it imposed the burden of adjustment almost entirely on the taxpayers of Greece and indirectly on the taxpayers of all eurozone states. The Greek rescue package will have the effect of increasing moral hazard for the creditors of EU sovereign states by incentivizing them to make more and riskier loans to eurozone states with the cost of any adjustment borne by the debtor state and indirectly by European taxpayers.

The confusion and delay in putting together the guarantee fed the flames of volatility and it is now not clear that even this sum will be enough. A more damaging sequence of events would be difficult to imagine, but worse may come. Having at last chosen to follow a sensible guarantee strategy as discussed below, the eurozone governments have proposed to resuscitate a modified version of the Stability and Growth Pact (SGP). The eurozone was and continues to be gripped by deficit hysteria, with all governments being forced

3 As ALAN GREENSPAN recounts in his autobiography: 'Mexico ended up using only a fraction of the credit. The minute confidence was restored, it paid the money back - the United States actually profited USD 500 million on the deal.' GREENSPAN (2007).

4 The North American Free Trade Agreement had liberalized much of cross-border finance and trade between Mexico and the US with the result that the two economies were increasingly integrated and exposed to the economic and social problems which both experienced. 
to commit to massive cuts in public expenditure. It appears that the path to recovery may be paved with higher unemployment and bankruptcy. ${ }^{5}$

\section{European Monetary Fund}

The absence of an EU sovereign debt restructuring framework and sovereign default mechanism has led to a proposal for a EMF which could provide financial support to EU states which have already adopted the euro. The proponents of the EMF, such as DANIEL GROS and THOMAS MAYER, argue that a sovereign default mechanism is necessary for the following reason:

The strongest negotiating asset of a debtor is always that default cannot be contemplated because it would bring down the entire financial system. This is why it is crucial to create mechanisms to minimise the unavoidable disruption resulting from a default. Market discipline can only be established if default is possible because its costs can be contained. ${ }^{6}$

The idea of the EMF is premised on the notion that sovereign defaults are good economic policy if a state has assumed unsustainable debt and that an orderly default can be permitted because its costs can be contained. This is an important assumption that drives the EMF proposal. The proposed EMF has been supported by the German Finance Minister and the IMF Managing Director.

The mechanics of the EMF would work as follows. The EMF will be financed by euro-area states paying a $1 \%$ levy on the value of their annual deficit exceeding $3 \%$ of GDP and on the value of their national debt exceeding $60 \%$ of GDP. The levy creates additional incentives for states to comply with the SGP's national debt limits by allowing the EMF to guarantee a Member State's debt up to a value of $60 \%$ of GDP. It would have responsibility for organizing an orderly sovereign default as a matter of last resort. ${ }^{8}$

The EMF will be allowed to borrow money on the capital markets. A Member State encountering financial difficulties would be allowed to submit a request for support but must submit a fiscal adjustment plan. If approved, the Member State can receive up to the amount of its contribution paid so far into the Fund. Proponents of the EMF assert that it can be implemented within the framework of enhanced cooperation, recognized by Article 20 of the Treaty on European Union (TEU) and by Articles 236ff. of the TFEU. The enhanced cooperation framework requires that once Council affirms that

5 As the Financial Times leader argued on 25 May 2010: 'growth is a precondition for stability, not something to be traded off against it. Putting countries on the rack of debt deflation will not stabilise their economies, only destabilise their politics'.

6 DANIEL Gros/Thomas MAYER, 'How to Deal with the Threat of Sovereign Default in EU: Towards a Euro(pean) Monetary Fund', Intereconomics - Forum 2 (2010): 64-68.

7 DOMINIQUE STRAUSS-KAHN, IMF Managing Director, Lecture at King's College, Cambridge, Institute for the Teaching of Economics conference (10 Apr. 2010).

8 GROS/MAYER (note 6). 
the measure in question has a valid Treaty objective, it must decide whether the Union acting as a whole can achieve the objective within a reasonable amount of time. If it cannot, Council can authorize enhanced cooperation in this area by a group of at least nine Member States, thus enabling those states to move ahead with the legislation in question and to adopt it for themselves. However, other states must be allowed to participate in the enhanced cooperation process if they comply with all the conditions laid down by the Council in its authorizing decision.

The EMF proposal is an important development in the debate over whether to establish a centralized sovereign default support mechanism in the EU. Under the proposal, it would be operated by the eurozone states but is open to participation by all EU states if they satisfy the requisite conditions. Serious legal concerns have been raised about whether the EMF can be established through the enhanced cooperation framework and whether it violates the no-bailout prohibition of Article 125 TFEU and whether it qualifies for the exceptions in Article 122 TFEU. ${ }^{9}$ It is submitted that in addition to the legal concerns, the adoption of the proposed EMF would represent a substantial centralization of EU institutional authority to provide guarantees to ailing EU sovereign debtors without an adequate framework to encourage or facilitate negotiations between creditors and sovereigns over the restructuring of sovereign debt. Nevertheless, the EMF proposal is under serious consideration by EU policymakers and will continue to play an important role in the debate over a reformed sovereign default mechanism in the EU.

\section{European Financial Stability Facility (EFSF)}

The EFSF was approved by Council on 10 May 2010 to provide funding support to eurozone states which are in financial difficulties. ${ }^{10}$ Eurozone states (excluding Greece) pledged EUR 440 billion in 2010 to the fund that will be guaranteed by these fifteen states according to their respective contributions to the capital of the European Central Bank. ${ }^{11}$ To enhance its creditworthiness, the fund has a cash reserve of $20 \%$ in addition to the amount pledged by each member. It was designed to be a short-term financing arrangement that would be available to eurozone states experiencing financial difficulties only for three years, after which, the fund would be dissolved if no

\footnotetext{
ULRICH HÄDE, 'Legal Evaluation of a European Monetary Fund', Intereconomics - Forum 2 (2010), 69-72.

10 Council Regulation No. 9606/2010. See also Decision of the sixteen euro-area Member States (7 Jun. 2010) (Luxembourg). The EFSF has a basic securitization structure but with no tranches. Unlike other securitizations, there is no actual exchange of collateral.

11 For example, Germany's pro rata share of the fund is EUR 122.85 billion, while France's share is EUR 92.3 billion and Italy has a EUR 81 billion share.
} 
member had drawn on it. ${ }^{12}$ As discussed below, however, the EFSF has issued bonds to pay for the Irish government's EUR 67.5 billion bailout; these bonds are scheduled to be paid off over a 10 to 20 year period. This means that the EFSF will need to be established on a more permanent basis beyond 2013. To ensure this, the Council of Ministers met in January 2011 and agreed that the EU Treaty (TFEU) would need to be amended to provide a permanent EU bailout fund and that the EFSF should be transformed into a permanent European Stability Mechanism (ESM). The details of the ESM will be agreed in 2011 followed by the necessary proposed amendments to the TFEU to be submitted for ratification in late 2011 and 2012. In the meantime, the EFSF will remain active in issuing bonds to provide the agreed upon loans for Ireland and possibly for other eurozone states, such as Portugal, who may seek financial assistance.

The EFSF relies for the most part on operational support from the German Debt Office and the European Investment Bank. It is an off-balance sheet special purpose vehicle that can issue bonds to the market and transfer the proceeds of the bond issuance to the eurozone states who have been approved for financial assistance. ${ }^{13}$ Before a euro-area member receives assistance, the Eurogroup must ask the IMF, the European Commission and the ECB to analyse the request and visit the country seeking assistance. Based on the Greek and Irish experiences, this may take about two weeks. The IMF and the EU institutions can then deliberate for another week or two before making the final decision to authorize the euro-area finance ministers to authorize the EFSF to raise money. At that point, the German Debt Office will work closely with the European Investment Bank (EIB) to issue the bonds as agent for the EFSF. ${ }^{14}$

12 The EFSF will close down in three years on 30 Jun. 2013, unless there is a financial operation in which a eurozone state draws on the fund, in which case the EFSF's existence would be prolonged until the last obligation was fully repaid.

13 It is not clear yet whether it will receive a Triple-A rating. The EFSF argues that the TripleA rating is justified based on the $20 \%$ reserve fund it will have in addition to the amounts contributed by each eurozone state.

14 The EFSF can guarantee bonds up to EUR 440 billion but in actual fact this will be much less at an amount of about EUR 250 billion (not enough to cover loans to other countries) because the guarantees apply to $120 \%$ of the value of the bonds based on the $20 \%$ excess cash reserve designed to enhance the creditworthiness of the bonds for a Triple-A rating. 
The European Financial Stability Facility

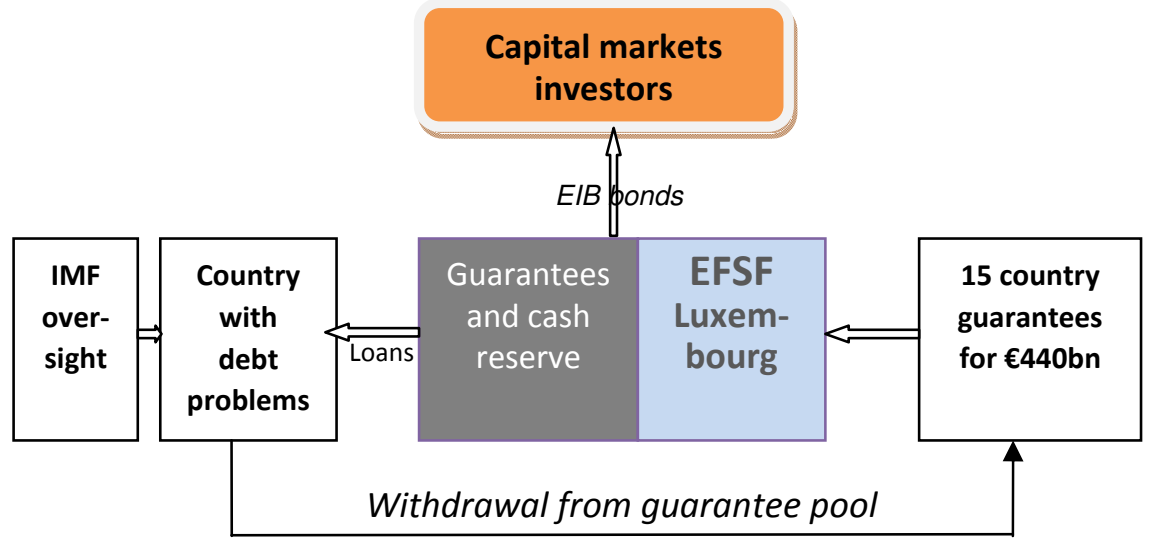

Source: The German Debt Office.

Much uncertainty surrounds the fund: little is known about whether investors will continue buying the bonds it issues if the fiscal positions of more eurozone states (who are guarantors) continue to deteriorate and they too apply for support from the fund, which is a strong possibility now for Portugal, Spain, Italy and Belgium. ${ }^{15}$ The fund has attracted criticism as 'an attempt to resolve the crisis with imaginary money rather than providing real money and having to find it somewhere'. ${ }^{16}$ Moreover, if several countries seek assistance at once, there is a risk that the fund could be exhausted, but fund proponents argue that this is unlikely because foreign investors are returning to the sovereign debt markets and China has even promised to buy the bonds of several ailing eurozone sovereigns. ${ }^{17}$ Euro-area states can also use the fund to bail out their banks. The recent sovereign debt problems of Ireland arising from it assuming substantial liabilities from its largest banking and financial institutions resulted in the EFSF's first bailout. The Irish experience suggests that other eurozone states with unsustainable fiscal positions will probably have to tap the EFSF as well.

The creation of the EFSF initially brought some stability to European financial markets and restored some investor confidence in Greek sovereign

15 The EFSF is incorporated and domiciled under Luxembourg law and KLAUS REGLING was appointed as chief executive on 1 July 2010

16 LIZ ChONG, 'Klaus Regling Explains the EU's Stability Fund', The Financial News, 8, (July 2010), quoting DAVID WATTS.

17 See comments of EFSF CEO KLAus REgLING Proponents citing the Chinese foreign exchange department's announcement in July 2010 that it would buy more Spanish government bonds. The Financial News, 'Special Purpose Vehicle Set on Rescue Mission', (July 2010), 9 . 
debt and in the debt of other vulnerable eurozone sovereign debtors. Nevertheless, EU financial markets remain fragile in 2011: Ireland was forced to seek a bailout because of the huge pre-tax losses of its largest banks which increased the costs of the country's credit default swaps (CDSs) by $40 \%$ since 1 August 2010. Ireland's fiscal position remains unsustainable and the probability is high that a restructuring Irish bondholder claims will be necessary with significant 'haircuts' ${ }^{18}$ The persistent troubles with Ireland's stateowned banks suggest that the newly created EFSF have not sufficiently eased investor concerns about EU financial institutions and by extension have rekindled fears about the solvency of some deeply indebted EU sovereigns, such as Greece, Belgium, Spain, Portugal and Italy. These concerns have led financial institutions in these countries to increase significantly their borrowing from the ECB in 2010 and early 2011. Moreover, as part of its emergency programme begun in May at the height of the Greek crisis to purchase eurozone sovereign bonds, the ECB continued to purchase substantial amounts of short-dated Irish bank bonds in an effort to reduce growing volatility in the Irish bond market based on investor concerns that the government will have to continue massive public support for Ireland's weakened banking sector. These developments suggest that volatility is returning to EU sovereign debt markets and that investor concerns have not been allayed by the muchheralded bank stress tests and the creation of the EFSF.

\section{Reforming Sovereign Debt Restructuring in the EU}

This chapter argues that a reformed institutional structure at the EU level to oversee sovereign debt restructurings and, in exceptional circumstances, sovereign defaults should be established based on a coherent set of principles that are linked to a new decentralized EU institutional structure with clear lines of responsibility and decision-making to facilitate negotiations between creditors and sovereigns during periods of financial distress. The desirability of a level playing field in the EU internal market suggests that such an approach can be based on a harmonized set of principles and guidelines across EU states that govern the application and operation of this sovereign debt restructuring process.

18 Indeed, there is agreement among most economists, including IMF economists, that Greece will have to restructure most of its existing debt, which is forecast to exceed $150 \%$ of GDP in late 2011. Moreover, there is tremendous political pressure on the newly-elected Irish government to seek a reduction in the interest rate on their loan from the EFSF and to seek a restructuring of the payment terms to bondholders of Irish banks in order to force a 'haircut' on their claims. See Wall Street Journal (Europe), 'A comprehensive guide to ending Europe's crisis' Charles Forrelle (25 Jan 2011), 4. 


\section{A Decentralized EU Institutional Approach}

The recent sovereign debt crisis and ongoing financial turbulence in global and European financial markets demonstrates the need for a more coherent and rational sovereign debt default and restructuring process. Such a process could reduce the uncertainty and thus the moral hazard for states to reach unsustainable debt levels by creating a more predictable sovereign debt restructuring process. A clearer procedural framework and set of principles applicable throughout Europe would lead to improved and more timely sovereign debt management decisions, thus reducing the likelihood of crises occurring and mitigating the associated costs. The aim for creating a more orderly sovereign debt restructuring process in Europe would be to increase the incentives that sovereigns have to pay their debts in full and on time. This will allow sovereigns to have continued access to capital at reasonable interest rates. To achieve this, a clearer EU legal and institutional framework should be established to reduce the uncertainty that now surrounds sovereign defaults and restructurings.

Recent proposals as discussed above for a EMF or the creation of a new EU agency with powers to arbitrate and resolve sovereign debt disputes would probably require amending the EU Treaty, which may not be a feasible political proposition at present. ${ }^{19}$ Instead, this section suggests that EU policymakers should consider the following principles and rules to provide more certainty to sovereign debt risk management for both sovereigns and investors. These would not necessitate Treaty changes, but would be feasible within the existing legislative instruments.

\section{a) Collective Action Clauses (CACs)}

CACs - also known as majority action clauses - allow a super-majority of, for example, bondholders holding a particular class of bond contracts to vote to restructure the financial or repayment terms of the bond. ${ }^{20}$ The bond contract could provide, for instance, that $75 \%$ of creditors - rather than $100 \%-$ of a certain creditor class vote to restructure the financial and repayment terms (i.e., lower the interest rate or extend the maturity of the debt, respectively). The super-majority's decision would bind the minority bondholders of the same class, thus preventing a small minority from delaying or other-

\footnotetext{
See discussion in HÄDE (note 9).

The financial terms of the contract would generally include the rate of interest (the coupon rate), the amount of the principal, and related financing terms, while the repayment terms would include the date of periodic payments and the means and place of payment, the loan's maturity date, and in some cases what amount of interest and principal would be included in each payment.
} 
wise disrupting a restructuring agreement, thereby making the restructuring process more predictable. ${ }^{21}$

First, sovereign debtors and investors should agree henceforth to incorporate CACs into sovereign bond contracts or sovereign loan contracts (i.e., bank loans) governed under the law of an EU state. Although investors and sovereigns are increasingly using CACs in their sovereign bond contracts following the Argentine default, significant differences in the structure of these contracts still exist, thus increasing uncertainty regarding the renegotiation of repayment terms and how the overall restructuring process would operate. Sovereign bond contracts issued by EU states should have harmonized legal templates governing their overall structure but would allow the parties to agree on some of the specific repayment terms.

Although a growing number of EU sovereign bond contracts contain CACs, the majority does not, which means that for most EU sovereign bond contracts the consent of $100 \%$ of the bondholders of a particular class of bonds are necessary to change the repayment terms of the bond. ${ }^{22}$ As a result, a small minority of bondholders can prevent a restructuring that the majority believe to be in their best interests. Rather, EU directives and regulations should require that all sovereign bond and loan contracts contain majority action clauses, but allowing the parties to agree on certain repayment terms, such as specifying the percentage of creditors holding a certain value of the debt (e.g., $85 \%, 75 \%$ or $65 \%$ ) to approve a change in payment terms (e.g., lower interest rate). EU law should also require that sovereign bond or loan contracts contain a clause describing the process through which sovereign debtors and creditors negotiate if a restructuring event were to occur. This clause would specify how the creditors would be represented and by whom and on what date, or within what period of time, the debtor must provide financial and other information to the creditors' representative. The representative would be authorized to act on behalf of the creditors in the negotiations and have discretion to act based on the instructions of creditors with a specified percentage value of claims. ${ }^{23}$

21 CACs are in all sovereign bonds issued under English law and are increasingly being used under New York law sovereign bond contracts, which by tradition required unanimity or $100 \%$ of creditors of the same class to vote to restructure the financial or repayment terms of the bond contract.

22 See ElMAR B. KOCH (2003), Challenges at the Bank for International Settlements: An Economist's (Re)view (Basel: Bank for International Settlements), 56-60, stating ' $[\mathrm{t}]$ raditionally, CACs were included in sovereign bonds governed by English, Japanese and Luxembourgian law. Sovereign bonds issued under US, German, Italian and Swiss law did not include CACs', and thus required unanimous approval by bondholders of a particular class of bonds to change repayment terms. Ibid., 60-65, providing data of the value of sovereign bond issuance with CACs.

23 The specified percentage value of claims would be provided in the repayment terms of the contract. Moreover, the representative, and not individual creditors, would have the author- 
Another important area concerns how the sovereign would initiate a restructuring. EU law could require that this could be provided in a clause describing what period of time - e.g., four weeks - for creditors to come together to obtain the relevant information regarding the sovereign's financial situation, choose a representative, and decide a timeline for the negotiation process. The notion of a 'cooling off' period or automatic stay on creditor action against non-sovereign corporate or individual debtors is already recognized in the insolvency laws of some countries, such as Chapter 11 of the US Bankruptcy Code. ${ }^{24}$ The contract would be required to state when the "cooling off' period would begin, e.g., the date when the sovereign notifies its creditors that it wants to restructure its payments and/or the date that the creditors appoint their representative. The duration of the cooling off period would be mandated by EU law at, say, sixty or seventy-five days. During this period, a temporary suspension or deferral of payments would be required and enforced by an EU court of law. EU law should mandate that the bond or loan contract should provide for the possibility of a suspension or deferral of payments and provide for damages or penalties for any creditor who violates the provision by seeking to enforce its claim without prior court approval.

\section{b) Implementation}

The decentralized approach that relies on regulating EU sovereign bond and loan contracts so that they contain CACs is not the only option that has been proposed for reforming the sovereign debt restructuring process. Of course, the IMF staff had proposed an international sovereign debt restructuring mechanism (SDRM) in 2002 that attracted much attention but was not approved because of US opposition. The SDRM would have provided a more centralized approach that would have involved amending the IMF Articles of Agreement in order to create a legally binding arbitration process in which a designated IMF tribunal would have mediated and approved any disputes regarding the restructuring of sovereign debt. ${ }^{25}$ The IMF's SDRM was criti-

ity to initiate litigation for breach of the bond or loan covenants, but only with the approval of creditors with a specified value of claims.

24 Although Ch. 11 of the US Bankruptcy Code does not apply to sovereign debt default or restructuring, Ch. 9 of the US Bankruptcy Code does provide insolvency proceedings and an automatic stay against creditor claims against a municipal or county government debtor while the sovereign debtor is formulating a repayment plan for judicial and creditor approval. While the automatic stay is in effect, secured creditors can petition the court for adequate protection of their collateral rights in eligible property owned or possessed by the debtor. In Chs 9 and 11, the automatic stay can remain in effect for up to a six-month period to allow the debtor an opportunity to negotiate with creditors and devise a comprehensive payment plan.

25 ANNE KRUEGER, A New Approach to Sovereign Debt Restructuring, 16 Apr. 2002, Washington DC, International Monetary Fund, www.imf.org/external/pubs/ft/exrp/sdrm/eng/sdr m.pdf ('SDRM - April version', 11-14). 
cized on the grounds that it was insufficiently market-oriented and required too much centralized authority at the international level by concentrating too much power in the IMF. These same criticisms are perhaps also applicable to recent proposals to create an EU Monetary Fund that would provide guarantees on sovereign debt and liquidity assistance for ailing EU sovereign debtors while negotiating creditor claims, or the creation of the EFSF, which also provides liquidity support and issues guarantees for eurozone sovereigns having financial difficulties.

On the other hand, one can question the viability of the decentralized approach on the grounds that there are multiple legal systems of contract law in the EU and that this might be difficult to harmonize in order to facilitate sovereign debt negotiations and restructurings. Another question concerns what is the scope of the debt subject to the CACs. In theory, there would be no reasonable justification on economic grounds to restrict the scope of such clauses to bond contracts. It is observed that such clauses are already incorporated in many syndicated bank loans. ${ }^{26}$ Another question concerns whether during a restructuring all the claims of different bond issues should be consolidated into a single class of creditors or, alternatively, whether all the claims of bondholders should be consolidated with the claims of other creditors (i.e., bank loans). Market-based practitioners appear to prefer an approach that consolidates the CACs and other clauses into debt on an issue-byissue or loan-by-loan basis. Any inconsistency in legal terms or requirements created by different types of issues or jurisdictions should be resolved by arbitration provided in the contracts or by an EU agency established (as discussed below) to apply the EU principles and guidelines governing sovereign debt restructuring.

Finally, the EU must have the institutional capacity to monitor the implementation of such debt contracts to ensure that vital data is communicated to creditors and debtors and that the parties negotiate terms and conditions with full access to relevant information. An EU sovereign debt agency could be created by Regulation to exercise such a function and would have authority to collect data and perform surveillance of sovereign debt markets and report market developments to the European Commission, Parliament and market participants. The responsibilities of a EU sovereign debt agency could include overseeing EU Member State sovereign debt practices and providing data to the market regarding the risks that certain bond and loan contracts pose and to

26 JOHN B. TAYLOR, 'Sovereign Debt Workouts: Hopes and Hazards', conference address, Washington DC, Institute for International Economics, (on file with author)(observing that such clauses are included in bank loan agreements). See also, STEVEN L. SCHWARCZ, 'Sovereign Debt Restructuring: A Bankruptcy Reorganization Approach', Cornell Law Review 85 (2000), 975, 982-984, and STEVEN L. SCHWARCZ 'Facing the Debt Challenge of Countries that are Too Big to Fail', Duke Law Working Paper, 1-7 (2008). 
make recommendations and, if necessary, 'name and shame' states which appear to be developing unsustainable debt positions.

The agency could also exchange information with the ECB, the European Supervisory Authorities and the European Systemic Risk Board regarding financial stability issues in the sovereign debt markets. Moreover, it would clarify the process how market participants could enforce their rights and obligations under the debt contracts in a court of law of an EU state, especially to ensure that any restructuring process is occurring according to contractual requirements.

\section{EU Financial Stability Fund}

The EU sovereign debt agency with responsibility for overseeing the implementation of the CAC approach to sovereign debt restructuring based on harmonized EU principles and guidelines could also administer the establishment of a EU 'stability' fund to which EU states experiencing short-term funding problems would have access for short-term funding during financial distress and crises until they regain access to capital markets. The EU 'financial stability' fund would be paid for by a small transaction tax on all sovereign bond sales. ${ }^{27}$ The tax could be imposed at a very low level - ten basis points $/ 0.10 \%$, or five basis points $/ 0.05 \%$ - so as not to distort significantly the sovereign bond market and it would be easily implemented by requiring the intermediary banks who execute the transactions to deduct the tax at the point of purchase and sale and pay on to national treasuries who would then have an obligation to pay the sums into the fund. The tax could also apply to sovereign debt derivative instruments (i.e., sovereign credit default swaps [CDSs]) or other instruments which use sovereign debt as a referenced asset. The tax would apply uniformly to all EU sovereign bond issuance and could even be extended to include a tax on bank loans to EU governments. The tax could provide a sustainable source of finance to assist EU sovereigns experiencing sovereign liquidity problems and help assist the implementation of any restructuring plans. In return for accessing the fund, states would be required to implement appropriate fiscal adjustments in order to bring their sovereign debt to sustainable levels over the medium term.

If instead the country is not merely illiquid, but insolvent, more drastic measures should be taken and the EU stability fund would continue to be available, but needs to be supplemented by a mechanism for determining collective guarantees. ${ }^{28}$ These should be offered on the basis of strict conditionality, in which the state in question may be required to undertake signifi-

27 See Kern AleXANDER ET AL., 'Crisis Management, Burden Sharing and Solidarity Mechanisms in the EU', Brussels, European Parliament, May 2010, 43.

28 This means that EU authorities should adopt criteria for determining whether a state is either illiquid or insolvent; or, if it is illiquid, at what point does it become insolvent? 
cant structural reforms to, for example, the fiscal system, the structure of macroeconomic management, or the labour market. Short-term austerity measures may be a necessary component of a rescue package. But their impact should always be assessed against the needs of medium-term recovery. This also means that the rules of the SGP that have so conspicuously failed should be reconsidered and possibly replaced.

The approach suggested above would involve a major rethink of the political economy of the EU in general and the eurozone in particular. It would require a significant change of direction in fiscal policy, including a harmonized EU framework consisting of principles and guidelines to govern the restructuring and default of a sovereign debtor. The absence of an EU regime governing the restructuring of sovereign debt has resulted in an under-pricing of the true costs of sovereign debt, as it creates a moral hazard for investors to take on too much sovereign debt because they perceive that euro-area states in particular will always bail them out to prevent a collapse of the eurozone. This has led to an under-pricing of sovereign debt which means that the full cost of sovereign debt has not been internalized by those who invest in it, thereby resulting in too much of it being issued. Moreover, investors would be able to price sovereign debt more efficiently if they had more certainty regarding the rules of debt renegotiation and the ability to coordinate their claims collectively with other creditors in a crisis and to obtain relevant information from sovereigns. Whether such an EU agency could be constructed to facilitate such negotiations and generate relevant information for creditors is a policy matter and legal issue that is beyond the scope of this brief study.

\section{EU Stability Mechanism}

The above proposal for EU collective action clauses and EU sovereign debt agency were made by the author in a report commissioned by the European Parliament in September 2010. Following this report in December 2010, the European Council, considering it necessary to establish a more permanent emergency financing mechanism for sovereign debtors, created in December 2010 a European Stability Mechanism (ESM) based on the current EFSF capable of providing financial assistance programmes for eurozone member states under strict conditionality. Significantly, the ESM will enjoy preferred creditor status for its loans to sovereign debtors which means that the claims of private sector creditors, such as bondholders, will be subordinated to ESM loans. ESM loans will only be disbursed to a eurozone state if it appears insolvent and it has agreed to a debt sustainability plan with the Commission and the IMF which must involve both an economic and fiscal adjustment programme and a comprehensive restructuring of creditor claims.

Under the proposal, the restructuring of creditor claims must involve the use of standardized and identical collective action clauses (CACs) to facilitate 
the bailing in of the private creditors while maintaining market liquidity. The CAC requirement derived from a commissioned report submitted to the European Parliament in August 2010 that recommended the use of CACs for all EU states along with a EU sovereign debt financing facility (see enclosed proposals). Eurozone governments will be required to issue CACs starting in June 2013 when the ESM begins its operations. The CACs would be similar to the CACs already in use under English and US law that are modelled in part on a G10 Report in 2002 recommending the use of CACs with 'aggregation clauses' that allow all debt securities issued by a state to be considered and voted on together as part of restructuring negotiations with the sovereign. Crucially, bondholders would be allowed to pass by a qualified majority vote a legally binding change to the terms of payment, such as a standstill, maturity extension, interest rate cut or reduction in principal, if the sovereign is unable to pay. This sweeping reform of the legal framework of sovereign debt finance and restructuring will take effect in June 2013 with the effectiveness of the framework being evaluated by the Commission and ECB in 2016.

\section{Conclusion}

ROLF H. WEBER's long time work analyzing the contours of EU banking and financial regulation provide important insights for how policymakers and regulators should consider financial stability issues that arise from sovereign debt crises. Indeed, his analytical framework of systemic risk in financial markets provides an intellectual framework for how we might analyse the relevant regulatory and legal issues involved in building a more effective crisis management mechanism as well as building a more durable regulatory regime to control systemic risk. The design of sovereign bond contracts and the regulation of sovereign bonds to control systemic risk is an important extension of the intellectual framework developed by Professor Weber for the regulation and control of systemic risk in financial markets more generally.

The EU Sovereign debt crisis of 2010 involving Greece and Ireland demonstrates how financial distress in one member state can rapidly spread through contagion channels to threaten the macroeconomic and financial stability of both the eurozone and the European Union and even have international ramifications. Although EU bank stress tests, reported in July 2010, calmed concerns about the health of EU banks by showing generally that EU banks were not inadequately capitalized nor dangerously exposed to sovereign debt, EU financial markets remain fragile. The renewed troubles with Irish banks and Ireland's and Greece's persistent sovereign debt problems suggest that the results of the stress tests have not sufficiently eased investor concerns about EU financial institutions and by extension have rekindled 
fears about the solvency of some deeply indebted EU sovereigns, especially Greece, Ireland, Portugal, Italy and Spain.

These developments suggest that volatility is returning to EU sovereign debt markets and that EU policymakers should consider whether Europe needs a formal EU sovereign default process to incentivize states to manage more effectively their sovereign debt and to promote a more orderly resolution of creditors' claims. This chapter examined a number of options, including the newly created EFSF, and suggests that European policymakers should focus reform efforts on adopting a decentralized sovereign debt restructuring process that emphasizes the use of CACs to facilitate negotiations and information flow between creditors and sovereigns regarding sovereign debt risks. EU directives and regulations, not necessitating Treaty changes, should harmonize the principles and guidelines that govern the operation of CACs, but parties should be permitted some freedom to decide the parameters of CAC negotiations and some aspects of the restructuring process.

An EU sovereign debt agency should be created to facilitate such negotiations and to serve as an information warehouse for creditors and sovereigns to obtain data on market developments relevant to the pricing of sovereign debt risk. The EU sovereign debt agency could also administer a European Financial Stability Fund that would be created to provide liquidity to states experiencing financial distress and undergoing a restructuring if the state in question fulfils the requisite conditions for obtaining support. The EU Financial Stability Fund would be financed by a transaction tax on all EU sovereign bond issuance, CDSs and other derivative transactions that reference EU sovereign bonds. The tax would be at a very low rate so as to not unduly limit the market and to raise adequate revenue to assist states with temporary liquidity problems. 